\title{
Enabling proteomics-based identification of human cancer variations
}

\author{
Jing Li ${ }^{1}$, Zeqiang Ma ${ }^{1}$, Robbert JC Slebos ${ }^{2}$, David L Tabb ${ }^{1,3}$, Daniel C Liebler ${ }^{1,2,3}$, Bing Zhang ${ }^{1 *}$ \\ From UT-ORNL-KBRIN Bioinformatics Summit 2010 \\ Cadiz, KY, USA. 19-21 March 2010
}

\section{Background}

Shotgun proteomics is a powerful technology for protein identification in complex samples with remarkable applications in elucidating cellular and subcellular proteomes [1,2], and discovering disease biomarkers [3,4]. Shotgun proteomics data analysis usually relies on database search. Commonly used protein sequence databases in shotgun proteomics data analysis do not contain mutation information. This becomes a problem in cancer studies in which the detection of disease-related mutated peptides/proteins is crucial for understanding cancer biology [5]. Including protein mutation information into sequence databases can help alleviate this problem.

\section{Results}

Based on the human Cancer Proteome Variation Database developed by us recently [6], which comprises 41,541 nonsynonymous SNPs in 30,322 proteins from the dbSNP database and around 9000 cancer-related variations in 2,921 proteins, we created a variation-containing protein sequence database and a data analysis workflow for mutant protein identification in shotgun proteomics (Figure 1). Applying this workflow on colorectal cancer cell lines identified many peptides that contain either non-cancer-specific or very important cancer-related variations, such as a known somatic mutation in K-Ras in HCT116 cell line. Our workflow for mutant peptide identification has been tested for compatibility with various popular database search engines including Sequest, Mascot, X!Tandom as well as MyriMatch.

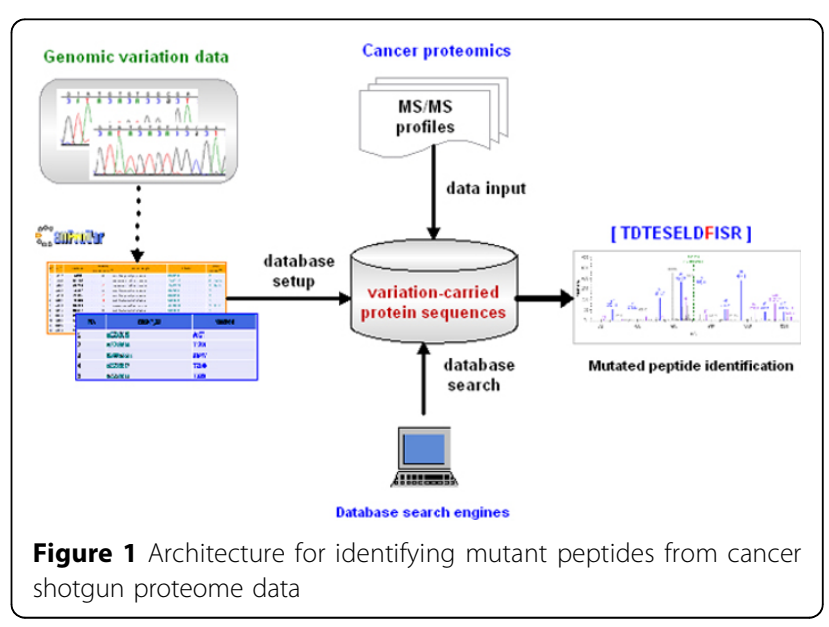

\section{Conclusion}

Owing to its protein-centric nature, the approach we proposed can serve as a bridge between genomic variation data and proteomics studies in human cancer.

\section{Acknowledgments}

This work was supported by the National Institutes of Health $(\mathrm{NIH}) /$ National Cancer Institute (NCI) through grant R01 CA126218 and the NIH/National Institute of General Medical Sciences through grant R01 GM88822.

\section{Author details}

${ }^{1}$ Department of Biomedical Informatics, Vanderbilt University School of Medicine, Nashville, TN 37232, USA. ${ }^{2} \mathrm{Jim}$ Ayers Institute for Precancer Detection and Diagnosis, Vanderbilt-Ingram Cancer Center, Vanderbilt University School of Medicine, Nashville, TN 37232, USA. ${ }^{3}$ Department of Biochemistry, Vanderbilt University School of Medicine, Nashville, TN 37232, USA.

Published: 23 July 2010

\section{References}

1. Foster $L$, de Hoog CL, Zhang Y, Zhang Y, Xie X, Mootha VK, Mann M: A mammalian organelle map by protein correlation profiling. Cell 2006, 125:187-199.

\footnotetext{
* Correspondence: bing.zhang@vanderbilt.edu

${ }^{1}$ Department of Biomedical Informatics, Vanderbilt University School of
} Medicine, Nashville, TN 37232, USA 
2. Kislinger T, Cox B, Kannan A, Chung C, Hu P, Ignatchenko A, Scott MS, Gramolini AO, Morris Q, Hallet MT, Rossant J, Hughes TR, Frey B, Emili A Global survey of organ and organelle protein expression in mouse: combined proteomic and transcriptomic profiling. Cell 2006, 125:173-186.

3. Decramer S, Wittke S, Mischak H, Zürbig P, Walden M, Bouissou F, Bascands JL, Schanstra P: Predicting the clinical outcome of congenital unilateral ureteropelvic junction obstruction in newborn by urinary proteome analysis. Nat Med 2006, 12:398-400.

4. Whiteaker JR, Zhang H, Zhao L, Wang P, Kelly-Spratt KS, Ivey RG, Piening BD, Feng LC, Kasarda E, Gurley KE, Eng JK, Chodosh LA, Kemp CJ, McIntosh MW, Paulovich AG: Integrated pipeline for mass spectrometrybased discovery and confirmation of biomarkers demonstrated in a mouse model of breast cancer. J Proteome Res 2007, 6:3962-3975.

5. Wang Z, Moult J: SNPs, protein structure, and disease. Hum mutat. 2001, 17:263-270.

6. Li J, Duncan DT, Zhang B: CanProVar: a human cancer proteome variation database. Hum Mutat 2010, 31(3):219-28.

doi:10.1186/1471-2105-11-S4-P29

Cite this article as: $L i$ et al:: Enabling proteomics-based identification of human cancer variations . BMC Bioinformatics 2010 11(Suppl 4):P29.

\section{Submit your next manuscript to BioMed Central} and take full advantage of:

- Convenient online submission

- Thorough peer review

- No space constraints or color figure charges

- Immediate publication on acceptance

- Inclusion in PubMed, CAS, Scopus and Google Scholar

- Research which is freely available for redistribution

Submit your manuscript at www.biomedcentral.com/submit
Ciomed Central 